\title{
Erratum to: Declining Fertility Rates in Japan: An Ageing Crisis Ahead
}

\author{
Peng Er Lam
}

Published online: 13 October 2009

(C) Springer Science + Business Media B.V. 2009

\section{Erratum to: East Asia \\ DOI 10.1007/s12140-009-9087-y}

Due to a technical error, the history dates of this article are wrong. The dates should read:

Received: 11 March 2009

Accepted: 31 July 2009

The online version of the original article can be found at http://dx.doi.org/10.1007/s12140-009-9087-y

P. E. Lam $(\bowtie)$

NUS, East Asian Institute, 469A Bukit Timah Road, Tower Block \#06-01, Singapore 259770, Singapore

e-mail: eailampe@nus.edu.sg 